\title{
FORESTRY AND FARMING $\rightarrow$ A PRACTICAL EXAMPLE
}

\author{
M. C. Farnsworth, A. J. R. Malee and I. Russell \\ Research Division, Pouto Forcsf Farm Lid, Te Kopuru
}

\section{A bstract}

The history and development of Pouto Forest Farm Ltd are outlined. Pouto Forest Farm is a forest farm project on the Pouto Peninsula, which has been in operation for five years on 3200 ha of land, of which 1890 ha are now planted in radiata pine. Brief consideration is given to the philosophy associated with the setting up of the project and to its prime stated 'objective, one of environmental betterment. Research and development work being undertaken at Pouto are also briefly outlined.

\section{INTRODUCTION}

THE CONCEPT of forest farming has been defined simply as making maximum productive and conservational use of marginal land according to its capabilities by a system of multiple land use involving a combination of forestry, improved pasture, grazed forest, and, in special cases, cropping (Farnsworth and Male, 1975a). It is the writers' opinion that to be carried out successfully forest farming involves careful planning with a full appreciation for the needs of trees, animals, crops, and man (Farnsworth and Male, 1975a).

A model ,of a forest farm development, pursued over the last $51 / 2$ years by Pouto Forest Farm Ltd, on the Pouto Peninsula south of Dargaville, is serving, we believe, as a practical 'demonstratioa of the economic potential of combining two forms of land use into a two-tiered land management system.

\section{POUTO FOREST FARM}

The company was set up in May 1970 with the purchase of 716 ha of land at Pouto, and the company planned the development of the forest farm scheme in a number of successive yearly phases. The fundamental phase had already been completed before the purchase of the area, this being the decision to use 40000 trees of Pinus radiata - planted by the previous owner - as a trial. This planting had taken place in 1968 in conjunction with the Northland Catchment Commission and it was the suc- 
cess of this which finally pointed the way for Pouto Foeest Farm Ltd to establish large areas of land in trees (Farnsworth, 1973).

The next three yearly phases (1970-1972) consisted of the purchase of further land, planting of blocks of land in rsdiata pine, and development of land both for planting and for pasture. The 1973-1975 phases consisted of further land development and planting of more trees (Table 1).

TABLE 1: DEVELOPMENT OF POUTO FOREST FARM

\begin{tabular}{lcccc}
\hline Year & Phase & $\begin{array}{c}\text { Land Purchases Land Planted } \\
(\text { ha })\end{array}$ & \begin{tabular}{c} 
Tha $)$ \\
\cline { 3 - 4 }
\end{tabular} \\
\hline 1970 & 2 & 716 & 283 & 4200000 \\
1971 & 3 & 764 & 490 & 000000 \\
1972 & 4 & 1108 & 341 & 500000 \\
1973 & 5 & 612 & 164 & 240000 \\
1974 & 6 & & 200 & 250000 \\
1975 & 7 & & 320 & 400000 \\
\hline
\end{tabular}

Pouto Forest Farm Ltd now has a 1otal land holding of 3200 ha of which some 1890 ha are planted in radiata pine. The general surface form of the farm is one of rolling hills of consolidated sands broken only by large, steep-sided gullies which dissect the eastern boundary. Over $60 \%$ of the total area can be traversed by tractor.

As at June 1975 some 3000 head of stock of all ages were being carried and the company is currently supporting six resident workers, eleven local workers and two resident scientists. The company is Auckland-based under the control of a baard of directors, but day-to-day management of the forest farm is in the hands of a resident manager who in turn is ably supported by a stock manager. For the purpose of this paper consideration will first be given to the forest farm areas and secondly to the area of existing pasture.

\section{FOREST FARM LAND}

It had been the intention of the company that potential forest farm land would first be improved by clearing and fertilizing with the idea of establishing a grass sward before the tree crop was planted. This would be followed by either rotoslashing or forage harvesting between the rows, and by regular topdressing. These actions would aid tree growth by releasing trees from possible grass competition and prevent costly deterioration in grass quality. 
At the same time, soil fertility would improve. But in practice it was found that it was not possible to obtain a well established pasture sward for the initial planting phases. These two planting phases - 1970 and 1971 - were in rough, partly developed country covered in low scrub, rushes, and grass species, such as ratstail (Sporobolus africanus), Danthonia spp., end Yorkshire fog (Holcus lanatus). It was decided to establish both pasture and trees at the same time. As the trees became established, coarse grass growth and volunteer growth of manuka (Leptospermum scoparium) and rushes (Juncus spp.) were regularly rotoslashed. This policy of rotoslashing has now resulted in an increase in the palatable higher quality grasses and legumes. Since these initial plantings, there has been a return to the original intention of developing the sward first before planting.

The planting regimes which have been used throughout the succsssive annual planting phases have remained flexible. Each block to be planted is carefully studied in order to work out the best possible planting technique to be employed. Experience at Pouto has shown that, although general planting guide-lines can be followed, what is suitable for oae area may not necessarily be suitable, for another. In general, three basic techniques of planting have been employed. These are: machine planting, conventional hand-planting, and "rotary-hoed dish" planting.

Machine planting is the principal method of planting used but is naturally limited by topographic features. Conventional handplanting is employed in those areas where machine planting cannot be carried out, and the rotary-hoed dish technique has been used in pasture areas dominated by Kikuyu grass (Pennisetum clandestinum) in an attempt to overcome the special problem of competition caused by Kikuyu grass (Farnsworth and Male, $1975 \mathrm{~b})$. The relative costs of these three planting methods are shown in Table 2.

Up to 1974 , although a great many different planting arrangements had been used experimentally, planting regimes had usually been at a $4 \mathrm{~m} \times 2 \mathrm{~m}$ spacing but this, of course, had varied

TABLE 2: PLANTING COSTS

\begin{tabular}{lllllll}
\hline Planting Method & & & \multicolumn{2}{c}{ Cost (\$/ha) } \\
\hline Machine planting & $\ldots \ldots$ & & $\ldots \ldots$ & 33.45 \\
Hand planting & $\ldots \ldots$ & $\ldots$ & & 46.76 \\
Rotary-hoed & dish & $\ldots .$. & $\ldots$ & $\ldots$ & $\ldots \ldots$ & 57.63 \\
\hline
\end{tabular}


with the type of country being planted and with the changing concepts relating to grazing policies. Where topographic features allowed machine forage \#harvesting, trees had been planted at a $5.5 \mathrm{~m} \times 3.5 \mathrm{~m}$ spacing, which in 1975 was changed to a $4.9 \mathrm{~m}$ x $2 \mathrm{~m}$ spacing. Forage harvesting between the new rows of trees was first introduced in 1974 in an attempt to overcome. pasture wastage during the first 18 months of the trees' estalishment, and November 1974 saw the harvesting of 1000 tonnes, of silage between the rows of trees planted in June of that year (Table 3).

TABLE 3: PERCENTAGE USE OF PASTURE AREAS OF FORES? FARM LAND AS COMPARED WITH ADJACENT OPEN PASTURE AREAS

\begin{tabular}{cc} 
Year & $\%$ Use \\
\hline 1 & 45 \\
2 & 55 \\
3 & 100 \\
4 & 100 \\
5 & 100 \\
\hline
\end{tabular}

All areas to be planted are prepared by rotoslashing and areas of tree lupin (Lupinus arboreus) are suppressed by aerial application of a mixture of 2,4,5-T and 2,4-D. In 1973, 2-year-old cattle were used to close-graze all areas before planting.

At present the tree crop is maaaged with the objective of attaining a timber crop of maximum volume and quality consistent with the maximum development of the multiple land use concept. The general management programme for the tree-planted areas is to introduce cattle $1 \frac{1}{2}$ to 2 years after planting. Before this, these areas are maintained by regular rotoslashing and/or fosage harvesting. Use has not been made of sheep because it was found that country which is only consolidated, wind-blown sand dunes tends to "break up" under their grazing. When the trees are 3 to 4 years old they are pruned and thinned. Further pruning and thinning will be carried out as required. A brief summary of each of the tree-planted areas is as follows:

The 1970 planting was reduced from the original 1480 stems/ha to between 600 and 800 stems/ha and pruned to an average height of $2 \mathrm{~m}$. The result of early pruning and of grazing pressure was a pasture dominated by leguminous species. 
The 1971 planting was reduced to about 1200 stems/ha and heavy growth of volunteer manuka was rotoslashed.

The 1972 and 1973 plantings were badly affected by two successive droughts and grazing.

The 1974 planting was equally divided between a rough, partly developed area and experimental plantings. The experimental plantings were in areas which had been undersown in high quality grasses and in areas dominated by Kikuyu grass. The trees were planted by the rotary hoe technique.

The 1975 planting was carried out on 320 ha of semi-developed country.

\section{Oplen pasture areas}

It must be stated from the outset that at Pouto, with tha exception of a few hay paddccks, all open pasture land and undeveloped land will eventually become forest farm land.

All areas which have not as yet been considered for planting are undergoing active development. Areas of tree lupin are being suppressed and many of the poorer quality pastures are being upgraded by undersowing and oversowing of high quality grass and clovers. For example, 1975 saw the undersowing of 75 ha of pasture with such grasses as: 'Grasslands Tama' Westerwolds ryegrass (Lolium multiflorum), 'Grasslands Ruanui' perennial ryegrass (L. perenne), 'Grasslands Huia' white clover (Trifolium repens), and 'Grasslands Turoa' red clover ( $T$. pratense). Sowing rates used per hectare were: $8 \mathrm{~kg}$ of Tama, $2.5 \mathrm{~kg}$ of perennial ryegrass, $1.25 \mathrm{~kg}$ of white clover, and $1.25 \mathrm{~kg}$ of red clover.

In April 1972 a heavy annual topdressing programme was instituted for all areas (including the tree-planted areas). In 1973, all were treated for trace element deficiencies, especially of boron, zinc, iron, copper, cobalt, molybdenum, and sulphur. It had been realized from an early stage that a correct balancs of trace elements was needed and the present plan is to maintain correct trace element levels for both trees and pasture by regular soil and herbage analysis.

To cope with the large numbers of cattle being run, large-scale yards were built in December 1973.

Each year some 12000 bales of hay are cut in addition to the silage cut between the rows of establishing trees.

In five years, productivity of the farm has been lifted from 5 livestock units/ha to an average of 12 livestock units/ha. 


\section{PHILOSOPHY, OBIECTIVES AND INTENTIONS}

The general philosophy behind the project was the ideal of making marginal land more economic and the foaest farm was set up with the firm belief that it would serve as a working model of a maximum land use concept. The prime stated objective was one of environmental betterment, this including 'both physical and social environment (Pouto Forest Farm Development Ltd, 1970) . Cumberland, in a report to the directcrs in 1973 on the project, stated that similar schemes to the Pouto project would be capable of not only transforming the landscapo and ameliorating the envircament of vast areas of the country but also of creating employment and social progress in isolated and relatively undeveloped regions.

These statements were in keeping with the initial stated intentions of the company which were to improve the physical envircnment and to foster the concept of multiple land use in its widest sense. The company also hoped to offer the fullest cooperation in the field of forest farm research and it was their intention to make freely available all information which would arise from work at Pouto.

To fulfil this aim a reesarch division was set up in December 1974 with its primary role to study different aspects of forest farming. Research topics currently under consideration at Pouto include: Forest influences on microclimates; establishment and growth trials (both for trees and pasture) ; use of colour infra-red for pasture studies; water resources and water-table management.

Finally, the question must have been asked just how important was the eccnomic motive behind the establishment of such a project? Initially the economic motive was of secondary importance as the project had been originally conceived to provide a practical demonstration of a forest farm. We firmly believe that we are achieving this aim.

\section{REFERENCES}

Cumberland, K, B., 1973. Report on Pouto Forest Farm Devetopment. Unpublished report, Pouto Forest Farm Ltd.

Farnsworth, M. C., 1973. Microclimates in a Forest Farm Plantation. Unpublished M.Sc. thesis, University of Auckland.

Farnsworth, M. C.; Male, A. J. R., 1975a. Farm Foresfry, 17: 10-S.

Pouto Forest Farm 1975b: N.Z. Farmer, 96: 63-4.

Pouto Forest Farm Development Ltd, 1970. Poufo Peninsula Environmental Betterment. Auckland. 